\title{
Genesis and Growth of the Yield Revolution in Wheat in India: Lessons for Shaping our Agricultural Destiny
}

\author{
M. S. Swaminathan
}

Received: 2 April 2013/Accepted: 31 May 2013/Published online: 23 June 2013

(C) NAAS (National Academy of Agricultural Sciences) 2013

\begin{abstract}
India, caused by a modification in plant architecture and physiological rhythm, through the introduction of the Norin dwarfing genes. This could be achieved with the help of Dr Norman E Borlaug, who supplied in 1963 the original breeding material carrying the Norin dwarfing genes. The grains of these varieties were, however, red in colour, which was not preferred for chapati (Indian bread) making. Through careful selection amongst segregating populations and breeding, high yielding amber grain wheat varieties with good chapati-making quality were developed. By generating synergy amongst scientific skill, political action and farmers' enthusiasm, it was possible to bring about a quantum jump in wheat production by 1968, when Ms Indira Gandhi, the then Prime Minister of India, released a special stamp titled 'Wheat Revolution'. In 2013, wheat production is likely to be of the order of 96 million tonnes from an area of about 29 million hectares. Producing 96 million tonnes at the 1963 yield level would have required at least 100 million hectares. This is why the yield revolution in wheat, and also in rice and other crops, is referred to as land- or forest-saving agriculture. Stimulating and sustaining farmers' interest in achieving higher productivity and production require sharply focused inter-disciplinary research, international collaboration, concerted and continuous attention to soil and plant health, and assured and remunerative marketing opportunities.
\end{abstract}

Keywords 'Krishi Darshan' · Norin dwarfing genes · Public policy · Wheat revolution

\section{Introduction}

2013 marks the 50th anniversary of the commencement of a yield revolution in wheat in India, caused by a modification in plant architecture and physiological rhythm. Changes in plant architecture involved the introduction of the Norin dwarfing genes, which helped to prevent lodging under conditions of good soil fertility and irrigation, thereby promoting greater translocation of photosynthates to grain formation, i.e. higher harvest index. Modification of the physiological rhythm resulted in making the crop relatively insensitive to a photoperiod. This was achieved by Dr Norman E Borlaug, who supplied in 1963 the

M. S. Swaminathan ( $\square$ )

M S Swaminathan Research Foundation, Chennai 600113, India

e-mail: swami@mssrf.res.in original breeding material carrying genes for dwarfing through shuttle breeding, i.e. selection in segregating populations grown under two diverse growing conditions. The multi-location trials conducted during 1963-1964 made it clear that semi-dwarf wheat varieties like Lerma Rojo 64A and Sonora 64 could help to increase the yield of wheat very considerably. The grains of these varieties were, however, red in colour. Through careful selection amongst segregating populations, it was possible to breed amber grain wheat varieties like Kalyan Sona and Sonalika characterized by good chapati-making quality. By generating synergy amongst scientific skill, political action and farmers' enthusiasm, it was possible to bring about a quantum jump in wheat production by 1968 , when Ms Indira Gandhi, the then Prime Minister of India, released a special stamp titled 'Wheat Revolution'. Later, Dr William Gaud [2] coined the term 'green revolution' to indicate the 
new opportunities for increasing production through a substantial rise in the productivity of crop plants.

The wheat revolution represented a significant landmark in India's agricultural history. Its genesis and growth have been analysed earlier [8]. Here, I briefly summarise the steps that led to the wheat revolution in India.

\section{Wheat Breeding Lines Containing the Norin Dwarfing Genes}

The Bengal Famine (1942-1943) provided the backdrop to India's Independence. The average yields were below $1 \mathrm{t} /$ ha in wheat and rice. Because of tall and thin straw, the then cultivated varieties were not responding well to fertilizers or irrigation [10]. Dr K Ramaiah, the first Director of the Central Rice Research Institute (CRRI), Cuttack, proposed that we should transfer genes for fertilizer response from japonica to indica rice varieties. This was the beginning of the breeding of high yielding varieties which subsequently led to 'the green revolution'. I worked at CRRI, Cuttack, on the indica-japonica hybridization programme for some time in 1954, before joining the Botany Division (later named by me as the Genetics Division) of the Indian Agricultural Research Institute (IARI). Dr B P Pal, Director of IARI and an eminent Wheat Breeder, agreed to my desire to work on semi-dwarf and fertilizer-responsive varieties of wheat using multiple research strategies, including radiation-induced erectoides mutants, on the lines of the work done by Prof A Gustafson in Sweden on developing the erectoides mutants of barley. Dr. Pal warmly supported my proposal and mentioned that breeding wheat varieties which can respond to fertilizer application was the need of the hour. Unfortunately, all the semi-dwarf strains we produced by different approaches had also reduced panicle size and hence a lower yield potential.

In 1955, I learnt from Dr H Kihara, the famous Japanese wheat scientist, that Dr Gonziro Inazuka of the Norin Experiment Station has semi-dwarf varieties with long panicles (i.e. without any pleiotropic effect) and that these were being used by Dr Orville Vogel in Pullman, Washington State, in his winter wheat breeding programme. I wrote to Dr Vogel and he was kind enough to send seeds of the semi-dwarf variety Gaines. He, however, also wrote that being a winter wheat, Gaines may not flower in Delhi. He therefore suggested that I approach Dr Norman Borlaug in Mexico who had incorporated the same dwarfing genes in a spring wheat background.

Dr Borlaug had entered some of his semi-dwarf material in the International Wheat Rust Nursery trials organised by the USDA. Dr M V Rao and I studied this material in 1961 at the IARI and were very impressed with the new plant type. I therefore requested Dr Borlaug to send a wide range of breeding material containing the Norin dwarfing genes. He promptly offered to send the seeds and expressed a desire to visit India to study the growing conditions before making a set to send to us. It took more than a year for the visit to materialise. Finally, he came to Delhi in March 1963, when he and I travelled all over the wheat belt in North India. Several of my colleagues like Dr S P Kohli, Dr M V Rao and Mr V S Mathur also accompanied him during some of the trips. At the end of the field trips, we decided on the following road map.

Dr Borlaug would send us by September 1963 about $100 \mathrm{~kg}$ seeds of each of four Mexican semi-dwarf strains, namely Sonora 63, Sonora 64, Mayo 64 and Lerma Rojo 64-A, selected on the basis of their good performance in Pakistan. I also requested him to send a wide range of segregating material (F2 to F7) so that we could make selections possessing resistance to the prevailing races of wheat rusts (stem, leaf and stripe rusts) as well as desirable culinary properties. We gave high priority to the genetic checkmating of wheat rust races. I explained to him that selection from crosses made in Mexico will help us to purchase time, since the quantity of wheat imports under the US PL-480 programme was increasing each year (it reached a level of 10 million tonnes in 1966).

\section{Breeding of Semi-dwarf Wheat Varieties Kalyan Sona and Sonalika}

The seeds from Mexico arrived in early October 1963. I immediately arranged their sowing at Indore, Kanpur, New Delhi, Ludhiana, Pant Nagar and Pusa (Bihar). Thus, a multi-location trial was organised in the very first year of this programme. Agronomic research was also started immediately under the overall guidance of Dr O P Gautam, at the Agronomy Division of the IARI, since it was clear that changes in several agronomic practices like depth of sowing, time of first irrigation, etc. would be needed in the case of the semi-dwarf strains. The agronomic practices needed in the case of the new plant type were standardised within a short time. Similarly, plant pathologists led by Dr R Prasada and Dr L M Joshi identified rust-resistant strains, and biochemist Dr A Austin assessed the chapati-making quality of the new varieties. Dr Borlaug was full of praise for this inter-disciplinary team work, particularly for the speed with which we developed new varieties from the segregating populations sent by him. The segregating material helped us to breed outstanding semi-dwarf varieties like Kalyan Sona and Sonalika, possessing amber grains and good yield potential. In contrast, the Mexican dwarf wheats had red grains. Kalyan Sona and Sonalika proved to be very popular with farmers. Consumers liked 
their chapati-making quality [4]. Incidentally, the name Kalyan Sona was a combination of the names Kalyan and Sona given for the same material by scientists in PAU (led by Dr D S Athwal and later, Dr K S Gill) and IARI. Since then, hundreds of high yielding varieties of Triticum aestivum, $T$. durum and $T$. dicoccum have been released by wheat scientists working under the All India Coordinated Wheat Improvement Project sponsored by the Indian Council of Agricultural Research (ICAR).

\section{Launching of Yield Revolution in Wheat}

Based on analysis of the results of the multi-location trials conducted during 1963-1964, I concluded that time has come to launch a yield revolution in wheat based on semidwarf, fertilizer- and irrigation water-responsive varieties. I therefore proposed in June 1964 the organisation of 1000 National Demonstrations in the fields of farmers with small holdings for introducing the new plant type to them. I emphasised that the demonstrations should be in the fields of resource-poor farmers, since the success of demonstrations in rich farmers' fields will be attributed to affluence and not to technology [5]. The Ministry of Agriculture had some reservations about this approach, but the then Minister for Food and Agriculture, Mr C Subramaniam, overruled the objections and approved the programme in August 1964. In the National Demonstration plots, laid out during 1964-1965, small farmers harvested 4 to $5 \mathrm{t} / \mathrm{ha}$ of wheat in contrast to less than $1 \mathrm{t} / \mathrm{ha}$ in the control plots. The success of the National Demonstrations unleashed the enthusiasm of farmers and a small government programme became a mass movement.

In 1964, a National Tonnage Club of Farmers was organised, the membership of which was confined to farmers producing about 2 t/ha of wheat or other crops. Thus, the seeds of the yield revolution were sown in the minds and outlook of small farmers.

In 1964-1965, I devised a two-pronged strategy for purchasing time in terms of seed multiplication. Because of the success of the National Demonstrations, the clamour for new seeds grew rapidly. The two-pronged strategy consisted of (a) organising the Jounti Village of Delhi State as a Seed Village. Seed technologist Dr Amir Singh, who knew the villagers well, played an important role in convincing them that they should take to the production of seeds of the new varieties. The second aspect of the strategy was to get bulk quantities of seeds from Mexico. Mr C Subramaniam and Prime Ministers Mr Lal Bahadur Sastri and Ms Indira Gandhi accepted our recommendation for the import of 200 and 18,000 tonnes of seeds of wheat vars Lerma Rojo and Sonara 64 in 1965 and 1966, respectively. These imports were done as a part of our 'purchase time' strategy. We then sent a team comprising Dr S M Sikka, Dr S P Kohli and Mr Vijayaraghavan to Mexico to purchase the seeds. They did a superb job and the seeds arrived by mid-September. The then Finance Secretary, Mr S Bhoothalingam, has chronicled these historic decisions in his book, 'Reflections on an Era' [1]. In 1967, Ms Indira Gandhi visited the Jounti Seed Village and inaugurated the Jawahar-Jounti Seed Cooperative [6].

Wheat production reached a level of 17 million tonnes in 1968 , in contrast to 12 million tonnes 4 years earlier. On my suggestion, Ms Indira Gandhi and the then Agriculture Minister Mr Jagjivan Ram released a special stamp titled, 'Wheat Revolution' in July 1968 (Fig. 1). The stamp had a picture of the IARI Library Building, to symbolise the role of science in the transformation of yield potential in wheat.

In 1968, about four million tonnes of additional wheat became available due to the high yielding varieties programme. Most of this belonged to the red grain Mexican wheat var. Lerma Rojo. The Agricultural Prices Commission recommended Rs. five more per quintal for amber grain varieties. It was clear that such a difference would dissuade farmers from growing the Mexican varieties during the following year. I mentioned to Mr Tony Dias, who was the then Food Secretary, that we should announce a uniform support price for amber and red grain varieties. $\mathrm{He}$ was kind enough to take me to the then Minister $\mathrm{Mr}$ Jagjivan Ram to explain the reasons why we should have a uniform price. After hearing me, Mr Jagjivan Ram announced in Parliament a uniform minimum support price of Rs. 65 per quintal for all wheat varieties. This decision of Shri Jagjivan Ram played a catalytic role in spreading the new high yielding varieties on a large scale during rabi 1968-1969 and in subsequent years. Meanwhile, we had intensified our work in developing new varieties with the desired culinary quality characters. Mr V S Mathur played

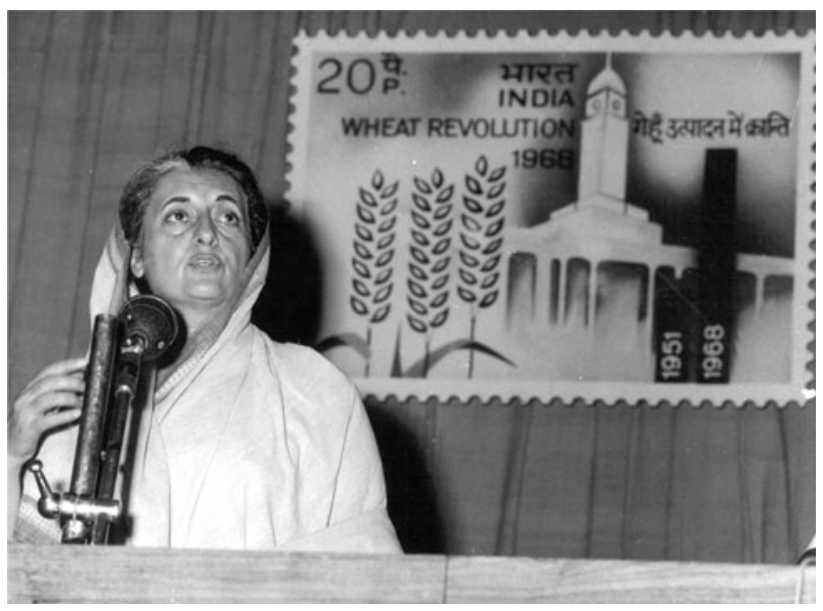

Fig. 1 Ms Indira Gandhi releasing the 'Wheat Revolution' postage stamp in July 1968 at the IARI, New Delhi 
a key role in the development of a range of very high yielding and high quality varieties. The early coordinators of the All India Coordinated Wheat Improvement Project, Drs A B Joshi, ${ }^{1}$ S P Kohli and M V Rao, played an important role in getting the new material tested all over the country for their yield potential and disease resistance properties. Dr Glen Anderson of Canada, whose services were provided by the Rockefeller Foundation, was a pillar of strength to the coordinated programme.

After his initial visit in 1963, Dr Borlaug invariably used to come for 7 to 10 days each year in March to study the progress being made both by scientists and farmers. His visits were a source of inspiration to scientists and farmers. We were lucky during 1964-1970 to have had strong public policy support from Ministers Mr C Subramaniam and Mr Jagjivan Ram and Prime Ministers Mr Lal Bahadur Sastri and Ms Indira Gandhi. Another key supporter was Mr B Sivaraman, the then Secretary, Agriculture.

\section{Synergy Between Science and Public Policy}

An important factor in stimulating accelerated growth in wheat productivity and production was the unhesitating support given by political leaders to scientific ideas. Mr C Subramanian was a pillar of strength throughout the 3 years he served as Food and Agriculture Minister (1964-1967). Mr Lal Bahadur Sastri, through his slogan 'Jai Jawan Jai Kisan', highlighted the critical role of farmers in not only feeding the nation but also in safeguarding its sovereignty. It was, however, Ms Indira Gandhi who clearly saw the link between food self sufficiency and our ability to adopt an independent foreign policy. No wonder that when Dr Vikram Sarabhai (Chairman of the Atomic Energy Commission) and I met her at her residence in late 1966 (the year she had taken over as Prime Minister) for discussing the opportunities opened up by remote sensing in natural resources mapping and management, the first question she asked me was, 'how soon can we build a food grain buffer stock of 10 million tonnes?'. I was a bit taken aback by this question, but on reflection, I realised that we had imported 10 million

\footnotetext{
1 Dr A B Joshi (late), who served as the first Coordinator of the All India Wheat Programme, made the following remarks in a letter to the National Academy of Agriculture Sciences on August 14, 1995 [3].

"Dr Swaminathan has been the most eminent research scientist whom India has ever produced - none like him in the past, and there shall be none in the far distant future. But for Dr Swaminathan, the Green Revolution in India would never have taken place. But for his contributions, India today would have been a decimated, depopulated country as prophesied by the American doom-sayers Paddock Brothers! Dr Swaminathan alone has been the Saviour of India".
}

tonnes of wheat in 1966 at the cost of heavy political humiliation. I replied, 'we should be able to build a grain reserve of 10 million tonnes by early 1970s, if farmers can be assured a remunerative price'. I further added that we should start building grain storage facilities in the areas of production like Punjab, Haryana and Western Uttar Pradesh. At that time, most of the grain storage facilities were located near ports. She mentioned this to Shri Morarji Desai, who was then Deputy Prime Minister and Finance Minister.

To the credit of Shri Morarji Desai, he soon took a meeting in the vicinity of the godowns of the Food Corporation of India located near the Indian Agricultural Research Institute and advised the FCI to come up with a plan for building grain storage structures in the production areas, using Usar land (i.e. salt-affected land with low agricultural production potential). Unfortunately, until today, lack of adequate facilities for the safe storage of food grains is our greatest weakness. I should, however, record the outstanding leadership provided by Dr S Pradhan, the then Head of IARI's Division of Entomology, in the development of the Pusa Bin, a farm-level storage structure.

Another decision by Indira Gandhi may be worthy of record. One evening in January 1967, Dr Vikram Sarbhai and I were returning after visiting several villages in Delhi State where semi-dwarf varieties of wheat were being cultivated. Vikram was impressed with the enthusiastic response of farmers to the new plant type. He told me that we should accelerate progress in bridging the gap between scientific know-how and farmers' do-how by the effective use of the radio and television. Vikram felt that we should communicate this immediately to Indira Gandhi. We went straight to her house from the village trip and fortunately she was free and gave a patient hearing. She then rang up the Minister for Information and Broadcasting and asked him to start a 'Krishi Darshan' programme immediately. Within a few weeks, the 'Krishi Darshan', a television programme aimed at disseminating information on new agricultural technologies to the farmers, was launched on 26 January, 1967. It played an important role in ushering the green revolution. The programme is still running and helping in improving agricultural productivity.

These few examples provide a flavour of the atmosphere prevailing in the 1960 s with reference to the interaction between scientists and political leadership. Ms Indira Gandhi's decision to build up substantial grain reserves, often against the advice of the Planning Commission, helped India to take an independent view on important issues, including the decision to carry out nuclear implosion tests at Pokhran in 1974 and 1998.

The term 'green revolution' refers to all crops where there has been a yield breakthrough. India's High Yielding 
Varieties Programme, initiated in 1967, included wheat, rice, maize, jowar (sorghum) and bajra (pearl millet). It must be emphasised that the green revolution became possible only because of synergy between technology, public policy and farmers' enthusiasm. Public policy with reference to input and output pricing and assured and remunerative marketing was absolutely essential to get the economics right and thereby sustain farmers' interest in producing more. This also became clear from the somewhat disappointing results of Dr Borlaug's efforts in Africa, where there was no arrangement for procuring the surplus grains from farmers at an assured minimum support price, thus emphasising that high yielding varieties alone would not help to accelerate production, unless coupled with the other essential inputs, particularly remunerative prices for the produce and assured marketing opportunities.

I captured the enthusiasm of farmers in the following words [12]: 'Brimming with enthusiasm, hard-working, skilled and determined, the Punjab farmer has been the backbone of the revolution. Revolutions are usually associated with the young, but in this revolution, age has been no obstacle to participation. Farmers, young and old, educated and uneducated, have easily taken to the new agronomy. It has been heart-warming to see young college graduates, retired officials, ex-army men, illiterate peasants and small farmers queuing up to get the new seeds. At least in the Punjab, the divorce between intellect and labour, which has been the bane of our agriculture is vanishing'.

On the occasion of receiving the Nobel Peace Prize in 1970, Dr Borlaug was gracious enough to write, 'The green revolution has been a team effort and much of the credit for its spectacular development must go to Indian officials, organisations, scientists and farmers. However, to you, Dr Swaminathan, a great deal of the credit must go for first recognising the potential value of the Mexican dwarfs. Had this not occurred, it is quite possible that there would not have been a green revolution in Asia'.

These developments emphasise that there is no miracle in agricultural progress-it involves hard and integrated work with concurrent attention to all links in the production, marketing and consumption chain. There would have been no wheat revolution without public procurement from farmers and without the work done by our wheat scientists in breeding very speedily high yielding varieties with amber grains and good chapati-making quality.

\section{Transition from Green to Ever-green Revolution}

I would also like to make a brief reference to the transition from green to ever-green revolution in agriculture. On 4 January, 1968, I made the following statement in my
Presidential address to the Agricultural Sciences Section of the Indian Science Congress held at Varanasi [7].

'Intensive cultivation of land without conservation of soil fertility and soil structure would lead ultimately to the springing up of deserts. Irrigation without arrangements for drainage would result in soils getting alkaline or saline. Indiscriminate use of pesticides, fungicides and herbicides could cause adverse changes in biological balance as well as lead to an increase in the incidence of cancer and other diseases, through the toxic residues present in the grains or other edible parts. Unscientific tapping of underground water would lead to the rapid exhaustion of this wonderful capital resource left to us through ages of natural farming. The rapid replacement of numerous locally adapted varieties with one or two high yielding strains in large contiguous areas would result in the spread of serious diseases capable of wiping out entire crops, as happened during the Irish Potato Famine of 1845. Therefore, the initiation of exploitative agriculture without a proper understanding of the various consequences of every one of the changes introduced into traditional agriculture and without first building up a proper scientific and training base to sustain it, may only lead us into an era of agricultural disaster in the long run, rather than to an era of agricultural prosperity'.

This statement was made early in 1968 before Dr William Gaud coined the term 'green revolution'. To achieve an ever-green revolution, we need technologies which can help farmers to improve productivity in perpetuity without associated ecological harm. By mainstreaming ecological principles in technology development and dissemination, we can achieve sustained and sustainable advances in productivity [9].

To sum-up, the seeds of the green revolution in India were sown in the fields of the Central Rice Research Institute, Cuttack, in the early 1950s through the indicajaponica hybridization programme and later in 1963 in the fields of the Indian Agricultural Research Institute, New Delhi. Research on semi-dwarf, non-lodging varieties was started at the IARI in the mid-1950s. The arrival and assistance of Dr Norman Borlaug in 1963 helped to accelerate the dwarf wheat breeding programme and purchase time in launching a yield revolution. The wheat improvement and production programmes were entirely conceived, planned and executed by us. We achieved rapid progress and proved the prophets of doom wrong only because we could achieve synergy among packages of technology, services and public policies. Dr Borlaug watched with great admiration the strategy and execution of 
the Indian Programme and tried to spread our strategy in other countries, particularly in Africa.

A systematic programme for breeding semi-dwarf wheat varieties which can utilize effectively fertilizer and irrigation water was started 50 years ago at the Indian Agriculture Research Institute, New Delhi, with the initial semidwarf material provided by Dr. Norman Borlaug in 1963. Thus, 2013 marks the 50th anniversary of the initiation of the semi-dwarf wheat breeding programme which ultimately resulted in the wheat revolution. This development, supported by various other steps taken by the Central and State Governments [11], has made it possible for us to plan on conferring a legal right to food with home-grown food to about seventy percent of our population through the National Food Security Bill currently under the consideration of Parliament. When enacted, the National Food Security Bill of India will be the largest social protection measure against hunger in the world.

The scientific and public policy initiatives described above led to the green revolution of the 1960s. Amongst them, sharply focused inter-disciplinary research and international collaboration are important. Eternal vigilance is the price of stable agriculture and this will call for concerted and continuous attention to soil and plant health and to the scientific checkmating of the adverse impact of climate change. At the public policy level, assured and remunerative marketing opportunities hold the key to stimulating and sustaining farmers' interest in achieving higher productivity and production. This is the pathway to shaping our agricultural future.

\section{References}

1. Bhoothalingam S (1993) Reflections on an Era. East-West Press Pvt. Ltd, Madras, pp 107-108

2. Gaud W S (1968) The green revolution: accomplishments and apprehensions. AgBioWorld. (Retrieved 10 May 2013)

3. Ramanujam S, Siddiq EA, Chopra VL, Sinha SK (2002) Science and agriculture: M S Swaminathan and the movement for selfreliance. Published on behalf of 21 Agricultural Societies of India, pp 401

4. Swaminathan MS (1965) The impact of dwarfing genes on wheat production. J I. A. R. I., P. G. School 3:57-62

5. Swaminathan MS (1966) National demonstrations in rice. Indian Farming 16(6):67-70

6. Swaminathan MS (1968a) The evolution and significance of Jounti seed village. Indian Farming, p 1-4

7. Swaminathan MS (1968) Presidential Address, Agricultural Sciences Section. Indian Science Congress, Varanasi

8. Swaminathan MS (ed) (1993) Wheat revolution: a dialogue. MacMillan India Ltd, Chennai, p 166

9. Swaminathan MS (2010) From green to evergreen revolution, Indian agriculture: performance and challenges. Academic Foundation, New Delhi, p 410

10. Swaminathan MS (2013) From Bengal famine to right to food, The Hindu

11. Swaminathan MS, Kesavan PC (2012) Agricultural research in an era of climate change. Agric Res. doi:10.1007/s40003-0110009-z

12. Swaminathan MS (1969) Punjab Miracle. The Illustrated Weekly of India 